\title{
KAJIAN PRAGMATIK PERCAKAPAN GURU DAN SISWA DALAM PEMBELAJARAN BAHASA INDONESIA DI SMA ADVENT BALIKPAPAN
}

\author{
Indah Ika Ratnawati \\ Pendidikan Bahasa dan Sastra Indonesia \\ Universitas Balikpapan \\ Jl. Pupuk Raya, Gn. Bahagia, Balikpapan, Kalimantan Timur \\ Email: ikaindah093@gmail.com
}

\begin{abstract}
Abstrak
Tujuan penelitian ini untuk mendeskripsikan tindak tutur Lokusi, tindak tutur Ilokusi, tindak tutur Perlokusi dalam percakapan guru dan siswa mata pelajaran bahasa Indonesia di SMA Advent kelas XI khususnya materi diskusi tahun ajar 2017. Dalam penelitian ini menggunakan jenis penelitian kualitatif deskriptif di mana data dalam penelitian ini berupa lisan atau ujaran percakapan antara guru dengan siswa dalam proses pembelajaran Bahasa Indonesia. Adapun instrument penunjang dalam penelitian ini yang digunakan oleh peneliti yaitu peneliti sendiri sebagai yang menjalankan dan tabel data.Hasil penelitian ini ditemuka tindak tutur Ilokusi berupa pernyataan 7 tuturan guru dan siswa. Tindak tutur Ilokusi ditemukan 26 tuturan, yang teridiri dari tindak tutur Ilokusi Asertif, tindak tutur Ilokusi Direktif dan tindak tutur Ilokusi Ekspresif. Tindak tutur Perlokusi ditemukan 16 tuturan yang berupa efek atau dampak linguistik dan nonlinguistik.
\end{abstract}

Kata kunci: tindak tutur, tindak tutur Lokusi, tindak tutur Ilokusi, tindak tutur Perlokusi

\section{Pendahuluan}

Bahasa sebagai alat komunikasi yang penting dalam kehidupan manusia.Penggunaan bahasa yang dipahami oleh penutur dan mitra tutur merupakan syarat terjadinya kelancaran dalam berkomunikasi. Tidak halnya dengan proses pembelajaran di kelas antara guru dan siswa bahasa merupakan alat untuk menyampaikan suatu materi dan menyampaikan sebuah argumen. Percakapan guru dan siswa di kelas tidak sekedar berbicara. Tetapi memiliki strategi berbicara dalam mencapai keberhasilan dalam pembelajaran. Percakapan guru dan siswa di dalam proses pembelajaran sangat menarik. Hal ini dapat diketahui interaksi guru dan siswa berdampak positif suasana komunikasi di kelas. Fungsi bahasa sebagai alat komunikasi menjadi sangatlah penting. Bahasa Indonesia sebagai alat komunikasi memiliki empat keterampilan berbahasa yaitu, keterampilan menyimak, keterampilan berbicara, keterampilan membaca, dan keterampilan menulis.Keempat keterampilan tersebut tidak dapat dipisahkan dalam berkomunikasi sehari-hari.

Terkait dengan urain di atas, dalam kajian linguistik dikenal dua kajian, yaitu kajian fungsional dan kajian struktural.Dalam hal ini, kajian yang digunakan dalam penelitian ini adalah kajian fungsional.Di mana penelitian ini mengkaji percakapan antara guru dan siswa SMA Advent 
Balikpapan kelas XI, khususnya kajian pragmatik. Kajian pragmatik menelaah ujaran-ujaran khususnya dalam situasi-situasi khusus dan memperhatikan pada aneka ragam cara yang merupakan wujud aneka konteks sosial.

Menurut Austin (Cummings, 2007: 8-9) menyatakan bahwa bahasa dapat digunakan untuk melakukan tindakan melalui pembedaan antara ujaran konstantif dan ujaran performatif.Ujaran konstantif mendeskripsikan atau melaporkan peristiwa-peristiwa dan keadaan-keadaan di dunin.Perbedaan konstantif dan performatif kemudian diganti pengklasifikasianya rangkap tiga terhadap tindak-tindak, yakni dalam bertutur, seseorang melakukan tindak lokusi, tindak ilokusi dan perlokusi.

Pada tahun 1962 dalam bukunya yang berjudul How to Do Things with Words Austin membedakaan tiga jenis ujaran yaitu, tindak lokusi (melakukan tindakan untuk mengatakan sesuatu), tindak ilokusi (melakukan sesuatu tindakan dalam mengatakan sesuatu), tindak perlokusi (melakukan sesuatu tindakan dengan mengatakan sesuatu), Tarigan (2007: 100).

Berdasarkan uraian di atas maka peneliti tertarik untuk mengkaji tentang kajian pragmatik percakapan antara guru dan siswa dalam pembelajaran bahasa Indonesia.Penelitian ini difokuskan pada siswa kelas XI SMA Advent Balikpapankhususnya pada tindak tutur lokusi, tindak tutur ilokusi, tindak tutur perlokusi percakapan guru dan siswa pembelajaran bahasa Indonesia.

\section{Metode Penelitian}

a. Subjek Penelitian

Subjek penelitian ini adalah guru dan siswa SMA Advent Balikpapan kelas XI.Dengan jumlah siswa 35 dengan perincian 15 siswa laki-laki, 10 siswi perempuan.

b. Lokasi Penelitian

Lokasi penelitian ini dilakukan di SMA Advent Balikpapan yang terletak di Jalan Kapten.P. Tendean No. 57 Rt. 50, Gunung Sari Ilir, Kecamatan Balikpapan Tengah, Balikpapan, Kalimantan Timur.

c. Data

Data dalam penelitian ini adalah ujaran percakapan antara guru dan siswa dalam pembelajaran Bahasa Indonesia

d. Sumber Data

Dalam penelitian ini sumber data berupa tuturan antara guru dan siswa dalam pembelajaran Bahasa Indonesia. 


\section{e. Teknik Pengumpulan Data}

Metode simak adalah metode yang digunakan untuk memperoleh data dengan menyimak penggunaan bahasa. Dinamakan metode simak karena cara yang digunakan untuk memperoleh data yaitu dengan cara menyimak penggunaan bahasa (Mahsun, 2007 : 29). Metode ini digunakan untuk mendapatkan data lisan, yaitu data berupa tindak lokusi, tndak tutur ilokusi, dan tindak tutur perlokusi percakapan guru dan siswa dalam pembelajaran bahasa Indonesia.

Dalam penelitian kajian pragmatik percakapan guru dan siswa dalam pembelajaran bahasa Indonesia di SMA Advent Balikpapan.Pengambilan data peneliti menggunakan teknik simak catat, di mana peneliti dalam pengambilan data menggunakan teknik simak catat.Peneliti menyimak percakapan guru dan siswa dalam bentuk merekam tanpa sepengetahuan guru dan siswa, selanjutnya peneliti melakukan tindakan mencatat hasil rekaman dalam bentuk transkip untuk memudahkan peneliti dalam mengklasifikasin tindak tutur lokusi, tindak tutur ilokusi, dan tindak tutur perlokusi.

\section{f. Instrumen Penelitian}

Menurut Sugiyono (2009: 102) instrument adalah suatu alat yang digunakan mengukur fenomena alam maupun sosial yang diamati.Pada penelitian ini yang menjadi instrument pertama adalah peneliti sendiri. Peneliti merupakan segalanya dari keseluruhan proses penelitian. Peneliti yang melakukan perencanaan, pelaksanaan pengumpulan data, analisis, penafsiran data, dan pelapor hasil penelitianya.Adapun instrument penunjang dalam penelitian ini yang digunakan oleh peneliti yaitu berupa tabel.Instrument penunjang untuk mempermudah dalam menganalisis dan mengolah data.

Tabel I

Tabel Data Penelitian

\begin{tabular}{|l|l|l|l|l|l|l|}
\hline NO & Tuturan atau Ujaran & Guru & Siswa & $\begin{array}{l}\text { Tindak } \\
\text { Tutur } \\
\text { Lokusi }\end{array}$ & $\begin{array}{l}\text { Tindak } \\
\text { Tutur } \\
\text { Ilokusi }\end{array}$ & $\begin{array}{l}\text { Tindak } \\
\text { Putur } \\
\text { Perlokusi }\end{array}$ \\
\hline 1 & & & & & & \\
\hline 3 & & & & & & \\
\hline
\end{tabular}

\section{g. Keabsahan Data}

Menurut Moleong (2006), agar suatu penelitian kualitatif itu dapat dipertanggungjawabkan keilmiahannya, perlu adanya usaha untuk meningkatkan derajat keterpercayaan data, yang disebutkan dengan keabsahan data. Keabsahan data dalam penelitian ini menggunakan cara, yaitu. 


\section{Ketekunan/Keajegan Pengamat}

Pengujian ini dilakukan dengan pendalaman data lebih rinci atau detail guna mencari kekonsistenan dan kerelevanan interpretasi terkait dengan proses analisis data. Dalam hal ini peneliti berpedoman pada "Lembar Pedoman Analisis Data" sebagai wujud temuan data (terlampir).

2. Triangulasi

Menurut Moleong (2006) triangulasi adalah teknik pemeriksaan data yang menggunakan sesuatu yang lain. Triangulasi dapat dilakukan dengan memanfaatkan (a) sumber, dengan membandingkan hasil pengamatan dan wawancara, membandingkan perkataan orang di depan umum dan secara pribadi, membandingkan perkatan orang tentang situasi penelitian dengan perkatannya sepanjang waktu, membandingkan pandangan tiap orang secara derajat biasa, menengah, dan tinggi, serta membandingkan hasil wawancara dengan dokumen terkait, (b) metode, berupa pengecekan derajat kepercayaan beberapa sumber data dengan metode yang sama, (c), penyidik, yaitu memanfaatkan orang lain yang terkait dalam penelitian guna mengurangi menyimpangnya pengumpulan data, (d), teori berupa pencarian pembanding teori lain dengan tujuan membuka peluang pada kemungkinan logis lainnya. Selain itu, peneliti juga mengacu teori-teori pada jurnal penelitian yang menggunakan analisis isi pada objek penelitian media massa.

3. Pemeriksaan Sejawat Melalui Diskusi

Teknik ini dilaksanakan dalam bentuk diskusi dengan rekan-rekan sejawat, guna memperoleh (a) sikap keterbukaan dan kejujuran untuk klarifikasi penafsiran, (b) kemungkinan terungkapnya segi-segi lain dalam pengujian hipotesis kerja, dan (c) kemungkinan menghilangkan sikap subjektivitas peneliti.

\section{h. Teknik Analisis Data}

Penelitian ini menggunakan teknik deskriptif kualitatif.Teknik analisis data yang digunakan adalah teknik analisis alir sebagaimana diungkapkan Miles dan Huberman (2009: 15-20). Teknik yang digunakan dalam menganalisis data sebagai berikut:

1. Reduksi Data

Setelah data terkumpul, selanjutnya dibuat reduksi data, guna memilih data yang relevan dan bermakna, memfokuskan data yang mengarah untuk memecahkan masalah, penemuan, pemaknaan atau untuk menjawab pertanyaan penelitian.Kemudian menyederhanakan dan menyusun secara sistematis dan menjabarkan hal-hal penting tentang hasil temuan dan maknanya. Pada proses reduksi data, hanya temuan data atau temuan yang berkenaan dengan permasalahan penelitian saja yang direduksi, sedangkan data yang tidak berkaitan dengan 
masalah penelitian dibuang. Dengan kata lain reduksi data digunakan untuk analisis yang menajamkan, menggolongkan, mengarahkan dan membuang yang tidak penting, serta mengorganisasikan data, sehingga memudahkan peneliti untuk menarik kesimpulan. Reduksi data pada tahap ini peneliti melakukan pengklasifikasian tuturan lokusi, tuturan ilokusi, dan tuturan perlokusi pada percakapan guru dan siswa dalam pembelajaran Bahasa Indonesia. Mengelompokkan kata-kata atau kalimat-kalimat tersebut ke dalam jenis-jenis tindak tutur lokusi, tindak tutur perlokusi, dan tindak tutur perlokusi

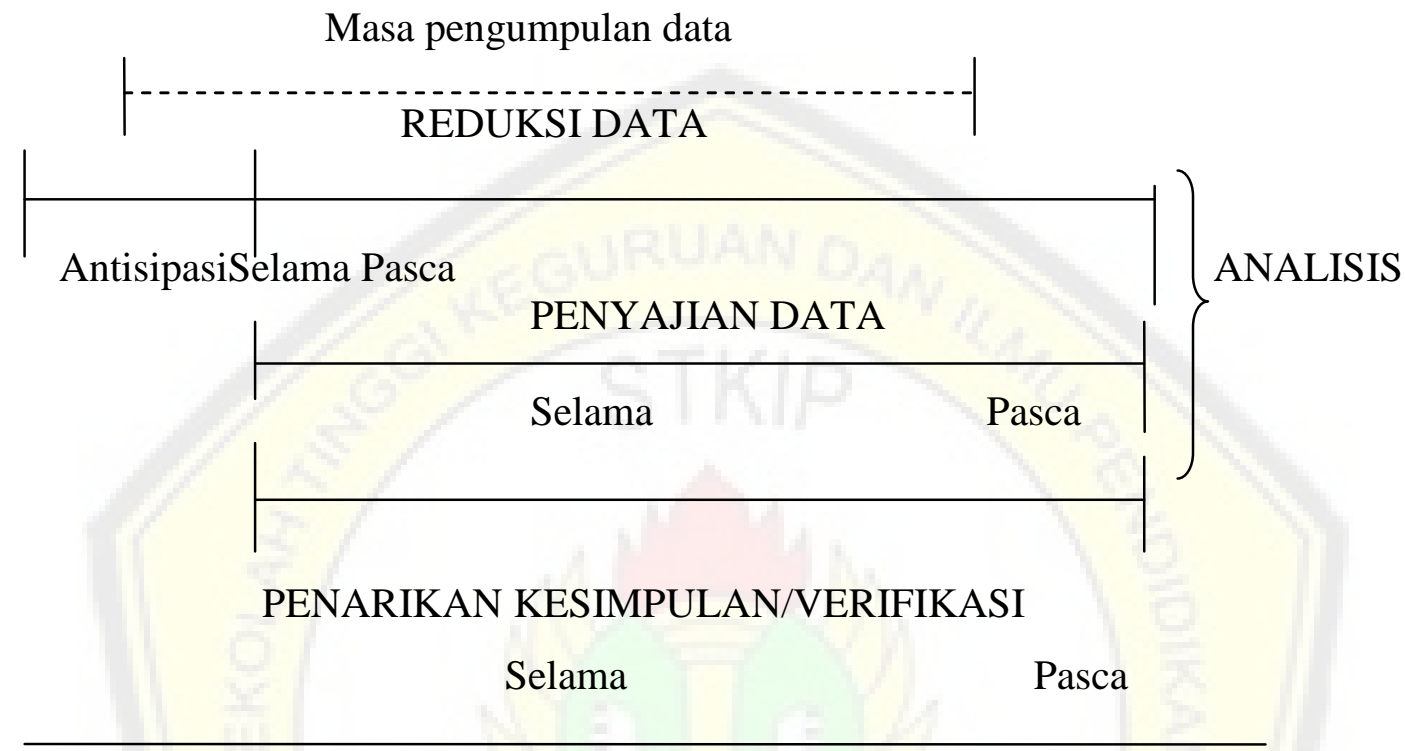

Gambar 1a Komponen-komponen Analisis Data: Model Alir

2. Penyajian Data

Penyajian data dapat berupa bentuk tulisan atau kata-kata, gambar, grafik dan tabel.Tujuan sajian data adalah untuk menggabungkan informasi sehingga dapat menggambarkan keadaan yang terjadi.Dalam hal ini, agar peneliti tidak kesulitan dalam penguasaan informasi baik secara keseluruhan atau bagian-bagian tertentu dari hasil penelitian, maka peneliti membuat tabel untuk memudahkan penguasaan informasi atau data tersebut.Dengan demikian peneliti dapat tetap menguasai data dan tidak tenggelam dalam kesimpulan informasi yang dapat membosankan.Hal ini dilakukan karena data yang terpencar-pencar dan kurang tersusun dengan baik dapat mempengaruhi peneliti dalam bertindak secara ceroboh dan mengambil kesimpulan yang memihak, tersekat-sekat dan tidak mendasar. Display data harus disadari sebagai bagian dalam analisis data.

a. Penarikan Kesimpulan

Penarikan kesimpulan dilakukan selama proses penelitian berlangsung seperti halnya proses reduksi data, setelah data terkumpul cukup memadai maka selanjutnya diambil 
kesimpulan sementara, dan setelah data benar-benar lengkap maka diambil kesimpulan akhir.

\section{Hasil Dan Pembahasan}

a. Tindak Tutur Lokusi

Pernyataan "ee maaf hari ini ibu yang terlambat" menjelaskan kepada muridnya bahwa hari ini yang terlambat adalah gurunya.Pada hari biasanya yang sering terlambat adalah muridnya.Pernyataan yang disampaikan oleh guru tersebut termasuk tindak tutur lokusi.Di mana pernyataanya mengandung makna menyampaikan keterlambatan hari ini.Pernyataan yang disampaikan guru tersebut tidak memberi efek bagi penyimaknya.

Guru:ee maaf hari ini ibu yang terlambat

Tuturan guru yang meminta maaf kepada siswa karena keterlambatanya ketika masuk di kelas.Hanya sekedar menyampaikan informasi kepada siswa dan tidak memberikan dampak berupa linguistik atau nonlinguistik.Karena tuturan yang disampaikan oleh guru kepada siswa berupa pernyataan yang memiliki makna.

Oc : saya akan mempresentasikan makalah ilmiah tentang kunyit.

Kalimat di atas dituturkan oleh penutur OC semata-mata untuk menginformasikan sesuatu kepada temannya, bahwa penutur OC akan menyampaikan materinya tentang kunyit. Tuturan OC termasuk tindak tutur lokusi bertujuan menyampaikan informasi kepada penyimak.Tuturan OC juga tidak memiliki efek bagi penyimak yang mendengarkan tuturan OC.

\section{b. Tindak Tutur Ilokusi}

Tuturan MS melaporkan kepada guru kalau MS tidak membawa makalahnya.Tuturan tersebut termasuk tindak tutur lokusi Asertif yang sifatnya melaporkan."Hal tersebut dapat ditunjukan pada tuturan "bu makalahnya lupa bawa bu”.Di mana tuturan tersebut memiliki makna bahwa MS menyampaikan informasi tidak membawa makalahnya, selain itu MS berharap kepada gurunya memberikan izin untuk tetap maju mempresentasikan dengan menggunakan HP.

Ms : : bu makalahnya lupa bawa bu

Guru : ya sudah gpp

Iw : Mae saya mau nanya?

Ss $\quad$ : belum (menegur Iw yang ingin bertanya kepada Ms, padahal Ms belum mempresentasikan makalahnya)

Tuturan SS" belum" termasuk jenis tindak tutur direktif. Di mana IW ingin mengajukan pertanyaan, pada hal MS belum mempresentasikan.Maka SS menegur dan memberikan informasi kepada IW belum dilakukan presentasi. 


\section{c. Tindak Tutur Perlokusi}

Tindak tutur Perlokusi merupakan tidak tutur yang yang berasal dari efek atau dampak dari tindak tutur Ilokusi.Tindak tutur Perlokusi bisa bersifat linguistik dan nonlinguistik.Dialog tersebut menjelaskan percakapan antara guru dengan siswa. Di mana guru menyuruh siswanya untuk membantu siswa lain mengangkat kursi. Pernyataan guru "ee dibantu angkat mejanya satu"termasuk tindak tutur Ilokusi dan peryataan guru berdampak pada IR yang mengangkat kursi termasuk tindak tutur perlokusi. Di mana siswa IR secara langsung mengangkat kursi tersebut. Efek yang berasal dari tuturan Guru berupa non linguistik.

$\begin{array}{lll}\text { Guru } & : \text { ee dibantu angkat mejanya satu ( guru menyuruh siswa laki-laki untuk } & \\ & \text { mengangkat meja dan kursi) } & \\ \text { Ir } & : \text { (mengangkat meja dan kursi yang disuruh oleh guru) } & \\ \text { An } & : \text { woi pakai sepatu woi (menegur temannya yang mengangkat meja } & \text { dan kursi } \\ & \text { yang tidak mengenakan sepatu) } & \\ \text { Ir } & \begin{array}{l}\text { (hanya tersenyum ketika temannya menegur ia yang tidak memakai } \\ \text { Menganjurkan }\end{array} & \text { sepatu) }\end{array}$

Dialog di atas mendiskripsikan AN menegur temannya yang mengangkat meja dan kursi yang tidak mengenakan sepatu. Pernyatan guru "woi pakai sepatu woi" termasuk tindak tutur Ilokusi.Tuturan guru tersebut berdampak pada IR yang berupa non linguistik yang berupa senyuman termasuk tindak tutur perlokusi.

\section{Simpulan}

Berdasarkan analisis dengan menggunakan kajian Pragmatik maka dapat disimpulkan sebagai berikut.

\section{a. Tindak Tutur Lokusi}

Tindak Tutur Lokusi adalah tindak tutur yang memberikan sebuah informasi kepada mitra tutur, kalimat yang diujarkan memiliki makna yang tidak berdampak atau tidak memberi efek kepada mitra tutur. Pada proses belajar mengajar mata pelajaran bahasa Indonesia dengan materi diskusi, peneliti menemukan 7 tindak tutur Lokusi. Tindak tutur Lokusi ditemukan pada ujaran guru bahasa Indonesia, karena tuturan guru bahasa Indonesia tersebut berupa pernyataan yang memiliki makna.

\section{b. Tindak Tutur Ilokusi}

Tindak tutur pada dasarnya pada saat seseorang mengatakan sesuatu, dia juga melakukan sesuatu.Dalam penelitian ini peneliti menemukan tindak tutur Ilokusi 26 tuturan antara guru dan siswa kelas XI pada materi diskusi. Tindak tutur Ilokusi dalam penelitian ini meliputi 
tindak tutur Ilokusi Asertif 'melaporka', tindak tutur Ilokusi Direktif (menegur, memohon dan meminta), dan tindak tutur Ilokusi Ekspresif (mengucapkan terimakasih). Dari tiga jenis tindak tutur Ilokusi tersebut paling banyak adalah Direktif. Di mana guru lebih banyak tuturan menegur dan meminta, dikarenakan pada saat proses belajar mengajar dimateri diskusi siswa tindak konduksif.

\section{c. Tindak Tutur Perlokusi}

Tindak tutur Perlokusi merupakan efek atau dampak dari tindak tutur Ilokusi. Dalam penelitian ini peneliti menemukan 16 tuturan dari percakapan antara guru dengan siswa pada saat proses belajar mengajar pada materi diskusi. Tindak tutur Perlokusi dalam penelitian ini terdapat tindak tutur Perlokusi yang berupa linguistik dan non linguistik. Di mana efek atau dampat dari tindak tutur Ilokusi lebih banyak non linguistik karena efek tersebut berupa senyuman termasuk tindak tutur perlokusi.

\section{Daftar Pustaka}

Cumming, Louise.2001. Pragmatik. Yogyakarta: Pustaka Pelajar

Cumming, Louise.2007. Pragmatic sebuah Perspektif Multidisipliner. Yogyakarta: Pustaka Pelajar

Chaer, Abdul dan Leoni, Agustina.1995. Sosiolinguitik Perkenalaan Awal. Jakarta: Rineka Cipta

Ibrahim. 1993. Kajian Tindak Tutur. Surabaya: Usaha Nasional

Moleong, Lexi. 2012. MetodePenelitian Kualitatif.Bandung: Remaja Rosdakarya

Nadar FX. 2008. Pragmatik dan penelitian Pragmatik. Yogyakarta: Graha Ilmu

Nadar FX. 2013. Pragmatik dan penelitian Pragmatik. Yogyakarta: Graha Ilmu

Rahardi ,Kunjana. 2005. Pragmatik: Kesantunan Imperatif Bahasa Indonesia. Yogyakarta: Erlangga

Ronadhi, Muhammad. 2014. Kajian Pragmatik Percakapan Guru dan Siswa pada Pembelajaran Bahasa Indonesia Kelas X SMA Negeri Miri

Rustono. 1999. Pokok-Pokok Pragmatik. Semarang. CV IKIP Semarang Press

Rustono. 2000. Implikatur Tuturan Humor. Semarang. CV IKIP Semarang Press

Sudaryanto. 1993. Metode dan Aneka Teknik Analisis Bahasa Pengantar Penelitian Wahana Kebudayaan dan Linguitik. Yogyakarta: Duta Waca University Press

Sugiyono. 2009. Metode Penelitian Kuantitatif dan Kualitatitif, R dan D. Bandung: Alfabeta

Tarigan, Henry, Guntur. 1990. Pengajaran Pragmatik. Bandung: Angkasa

Tarigan, Henry, Guntur. 2009. Pengajaran Pragmatik. Bandung: Angkasa

Yule, George. 2014. Pragmatik. Pustaka Pelajar: Yogyakarta 
Yuliani, Rina. 2013. Daya Tindak Tutur Guru dan Siswa dalam Pembelajaran Bahasa Indonesia pada Sekolah Menengah Pertama 